\title{
ANALISIS PENGARUH MODERASI KUALITAS AUDIT PADA HUBUNGAN HARGA PASAR SAHAM DAN GOODWILL DI INDONESIA
}

\author{
Almatius Setya Marsudi ${ }^{1}$ \\ ${ }^{1}$ Jurusan Akuntansi, Universitas Atma Jaya Indonesia \\ Email:almatius.marsudi@atmajaya.ac.id
}

\begin{abstract}
ABSTRAK
The study on intangible assets, goodwill in particular, becomes an interesting topic to reinvestigate since question about the relevance value is often discussed recently. This research aims to test the relevance value of goodwill information and see the effect of moderation variable of audit quality on the relevance value of goodwill.

The research was conducted on the companies listed in Indonesia Stock Exchange with regression analysis. The value model of stock exchange as the function from Book Value and Earning was used and the content analysis was conducted when assessing the goodwill of company.

With 71 non-financial companies in Indonesia as the samples, this research shows the result that the goodwill has a significant negative relation on stock price. It was also proven that the audit quality improves the relevance value of goodwill. This improvement makes the role of auditor important in assessing the accurate goodwill value.
\end{abstract}

Kata kunci: Value Relevance, Goodwill, Moderating, Audit Quality

\section{PENDAHULUAN}

\section{Latar Belakang}

Investor dalam melakukan investasi banyak menggunakan pertimbangan agar dapat menginvestasikan dananya di perusahaan yang memberikan return dan dividen yang menguntungkan. Relevansi nilai atas informasi yang diberikan perusahaan (value relevance) menjadi rujukan investor melakukan investasi. Relevansi nilai informasi akuntansi sendiri mengalami penurunan dari tahun ke tahun. Dalam penelitian Barth et al. (2001) menyebutkan relevansi nilai laba bersih paling tinggi di angka 10 persen.

Penelitian di Indonesia yang mengkaji tentang relevansi nilai tidak konsisten. Dalam penelitian Mayangsari (2004) dilaporkan telah terjadi penurunan nilai buku ekuitas dan laba bersih terjadi pada periode 1995-1998. Dilain pihak Suwardi (2005) menyebutkan bahwa relevansi nilai buku ekuitas dan laba bersih meningkat selama tahun 1992-1994, 1996-1997, dan 1999-2001, akan tetapi juga ditemukan menurun pada periode 1995-1998. Fluktuasi tersebut juga di temukan dalam penelitian Lako (2006) relevansi nilai informasi akuntansi dilaporkan menurun pada tahun 1997, 1999, 2001 dan 2003 sedangkan pada tahun 1996, 1998, 2000, 2002 dan 2004 meningkat.

Relevansi informasi akuntansi menjadi bagian yang tidak terpisahkan dalam menilai harga saham (Lo \& Lys, 2000), salah satu komponen yang menentukan adalah aset tidak berwujud yang diasosiasikan dengan harga saham (Camara, 2007). Diantara aktiva yang ada di industri modern, terdapat aktiva yang mendominasi laporan posisi keuangan yaitu aktiva tidak berwujud (Bloom, 2009). Goodwill merupakan salah satu contoh aktiva tidak berwujud, kajian akan Goodwill dalam penelitian akuntansi terus muncul khususnya akan pengakuan nilai goodwill seperti penelitian goodwill pada perusahaan manufaktur untuk melihat nilai perusahaan Chauvin (1994), sedangkan penelitian goodwill yang mengkaitkan amortisasi goodwill dengan nilai perusahaan yang berdampak pada harga saham dapat ditemui dalam penelitian Amir et al. (1993) yang mengkaji relevansi nilai dan ekuitas pemegang saham, ditemukan bahwa goodwill berhubungan dengan market to book ratio dan masih memandang goodwill sebagai sebuah aset. Menurut PSAK 22/IFRS 3 goodwill adalah aktiva yang mencerminkan manfaat ekonomi masa depan yang muncul dari aktiva lainnya. Aktiva tersebut diperoleh dalam kombinasi bisnis tidak teridentifikasi secara individual dan diakui secara terpisah. Goodwill sendiri menurut PSAK No. 22 masih memunculkan perdebatan menarik terkait adanya pilihan untuk mengukur kepentingan non-pengendali yang tidak perlu dilakukan 
secara taat asas dari satu kombinasi bisnis ke kombinasi bisnis lainnya. Kalau mengacu IFRS 3 goodwill harus dikapitalisasi dan diuji penurunan nilainya setiap tahun, goodwill disajikan dengan nilai wajar (nilai wajar) dengan pengukuran melalui uji penurunan nilai, kedepannya peran jasa penilai (appraisal) dibutuhkan dalam menilai kewajaran aktiva (khususnya aktiva tidak berwujud). Dengan demikian manajemen dapat merefleksikan informasi internal perusahaan dimasa depan dalam bentuk goodwill dalam laporan posisi keuangan (Rammana \& Watts, 2009). Karena sulitnya mengidentifikasi nilai dari goodwil dan adanya tuntutan dari standar akuntansi yang mengharuskan goodwill untuk dikapitalisasi dan diuji penurunan nilainya setiap tahun membuat peneliti termotivasi untuk menguji relevansi nilai atas goodwill.

Penelitian Barth et al. (1990) memandang revaluasi aktiva keuangan baik yang berwujud dan tidak berwujud memiliki relevansi nilai. Maines and Wahlen (2006) mengungkapkan bahwa keandalan merupakan karakteristik penting dalam informasi akuntansi agar bermanfaat. Oleh karena itu informasi akuntansi yang berkualitas adalah yang relevan dan dapat diandalkan, atau dengan kata lain informasi akuntansi dapat dipercaya untuk mengambil keputusan. Kepercayaan atas laporan keuangan perusahaan bergantung pada kualitas auditor dan independensi auditor. Dalam hal ini dibutuhkan audit yang berkualitas untuk menjamin kualitas laporan keuangan dalam pengambilan keputusan. Goodwill adalah aktiva yang sulit dilaporkan karena secara karakteristik tidak nyata, dan adanya kewajiban untuk menyajikan dalam bentuk nilai wajar, maka auditing memiliki peran yang penting untuk memastikan keakuratan penyajian dalam laporan keuangan. Kualitas audit yang dilihat dengan ukuran KAP menjadi faktor penting dalam proses penyajian goodwill dan nilai wajarnya (Hidayat, 2012).

\section{Rumusan Masalah}

Oleh karena masih terdapatnya perdebatan atas pengakuan dan pencatatan goodwill dan upaya pengembangan penelitian yang lebih lanjut, maka masalah penelitian ini dirumuskan sebagai berikut: (1) Apakah goodwill, EPS dan Nilai Buku Ekuitas Minus Goodwill berpengaruh pada harga saham? (2) Apakah kualitas audit mempengaruhi hubungan antara goodwill, EPS dan Nilai Buku Ekuitas Minus Goodwill dengan harga saham?. Tujuan penelitian ini adalah (1) menganalisis pengaruh antara goodwill, EPS dan Nilai Buku Ekuitas Minus Goodwill dengan harga saham (melihat relevansi nilai goodwill). (2) menganalisis pengaruh moderasi kualitas audit pada hubungan goodwill, EPS dan Nilai Buku Ekuitas Minus Goodwill dengan harga saham. Perbedaan penelitian ini dibandingkan penelitian sebelumnya adalah dengan menambahkan variabel moderasi kualitas audit yang diukur dengan ukuran KAP, penambahan variabel moderasi ini belum pernah diuji dalam penelitian sebelumnya pada model yang sama, argumentasi yang mendasari adalah kualitas audit yang tinggi akan mendorong pelaporan goodwill yang lebih baik dan kemudian mempengaruhi harga saham.

Penelitian ini diharapkan memberikan kontribusi pada keilmuan akan relevansi nilai, khususnya relevansi nilai pada goodwill dan dampaknya pada harga saham dimasa datang.

\section{KAJIAN PUSTAKA}

Signalling Theory menekankan akan pentingnya informasi yang dikeluarkan oleh perusahaan terhadap keputusan investasi pihak diluar perusahaan. Informasi yang lengkap, relevan, akurat dan tepat waktu sangat diperlukan oleh investor dipasar modal sebagai alat analisis untuk mengambil keputusan investasi. Pihak perusahaan akan cenderung mengungkapkan informasi yang baik (good news) dan informasi tersebut akan menjadi sinyal bagi investor untuk melakukan investasi.

\section{Goodwill}

Goodwill merupakan topik yang menarik untuk diteliti oleh karena goodwill tidak dapat diukur langsung nilainya, nilai tersebut banyak ditentukan oleh appraisal. Hal ini menyebabkan Goodwill banyak ditentukan dengan penilaian subyektif manajemen. Terdapat banyak perdebatan atas pengakuan nilai goodwill dibidang akuntansi dan tidak ada jawaban tunggal atas permasalahan akuntansi ini (Johnson \& Tearney, 1992). Banyak negara telah melakukan perubahan aturan terkait dengan pancatatan dan pengakuan goodwill. 
Di Indonesia sendiri sudah lama Goodwill diatur sesuai dengan Pernyataan Standar Akuntansi Keuangan (PSAK) No.22 tentang Akuntansi Penggabungan Usaha, dalam standar tersebut goodwill diamortisasi sebagai beban selama masa manfaatnya. Periode amortisasi goodwill selama lima tahun dan dapat diperpanjang sampai dengan 20 tahun. Ketika perusahaan pengakuisisi memiliki prospek di masa depan yang baik, semakin besar keinginan perusahaan pengakuisisi untuk membeli perusahaan yang akan di akuisisi, dampaknya semakin besar pula selisih nilai pembelian dengan nilai wajarnya. Hal tersebut membuat goodwill yang muncul dari proses akuisisi semakin besar. Pendekatan amortisasi mendapat kritikan tajam karena tidak memperlihatkan nilai sesungguhnya dari aktiva, dengan alasan goodwill dianggap mengurangi laba dan akan menurunkan nilai saham perusahaan (Jennings et al., 2000).

Kajian akan goodwill dalam penelitian akuntansi terus muncul khususnya akan pengakuan nilai goodwill seperti penelitian goodwill pada perusahaan manufaktur sebagai alat untuk menilai perusahaan Chauvin (1994). Goodwill sendiri menurut PSAK No. 22 (revisi 2010) masih memunculkan perdebatan yang menarik terkait adanya pilihan untuk mengukur kepentingan non-pengendali yang tidak perlu dilakukan secara taat asas dari satu kombinasi bisnis ke kombinasi bisnis lainnya dapat diterima oleh otoritas perpajakan. Kalau mengacu IFRS 3 goodwill harus dikapitalisasi dan diuji penurunan nilainya setiap tahun, dan disajikan dengan nilai wajar.

Beberapa penelitian yang menguji nilai ekonomis dari goodwill juga menemukan hasil yang menarik terkait dengan relevansi nilai, seperti penelitian yang dilakukan oleh Senthilnathan (2010) yang menemukan bahwa amortisasi goodwill yang positif menunjukkan hubungan yang positif signifikan dengan pendapatan bulanan. Hal ini menunjukkan kalau investor mungkin mempertimbangkan positif amortisasi. Goodwill merepresentasikan penciptaan elemen kekayaan di perusahaan, karena amortisasi goodwill adalah item akuntansi non-cash yang dihasilkan dari aktivitas akuisisi, dan tujuan dari kegiatan akuisisi mungkin diharapkan menciptakan kekayaan. Hasil penelitian menunjukkan bahwa perusahaan dengan positif amortisasi goodwill memberikan pendapatan yang lebih tinggi. Penelitian lain dilakukan oleh Richardson and Hirschey (2002), yang menemukan efek negatif harga saham dihubungkan dengan keputusan penghapusan goodwill, hal ini mengindikasikan bahwa angka goodwill akuntansi menggambarkan aspek signifikan dari dimensi nilai perusahaan yang tidak kelihatan.

\section{Kualitas Audit (Audit Quality)}

Banyak penelitian dilakukan untuk mengkaji kualitas audit seperti DeAngelo (1981) yang melihat kualitas audit dikaitkan dengan ukuran KAP audit. Dengan ukuran perusahaan yang besar ketersediaan dana dan teknologi untuk melakukan proses pemeriksaan menjadi lebih memungkinkan dan mendorong kualitas audit yang lebih baik.

Ukuran perusahaan audit dan independensi menjadi ukuran dari kualitas audit juga di teliti oleh (Francis, 2011) yang menemukan bahwa pada perusahaan kantor akuntan publik besar memiliki pengalaman dan ketrampilan yang lebih baik untuk melaksanakan proses pemeriksaan yang lebih berkualitas dibandingkan dengan Kantor Akuntan Publik kecil, hal tersebut bisa dilihat dari ketersediaan teknologi dan sumber daya manusia yang lebih baik.

Lee et al. (2007) dalam penelitiannya menemukan kualitas audit yang diukur dari kemampuan pemakai laporan keuangan dalam mengantisipasi keuntungan yang diperoleh dimasa depan akan lebih baik bila laporan keuangan tersebut di audit oleh Kantor Akuntan Publik Big Four. Dalam penelitian tersebut juga terbukti kalau bahwa laporan keuangan yang diperiksa oleh auditor dari Kantor Akuntansi Big Four memberikan gambaran yang lebih jelas pada investor untuk memprediksi masa depan.

Hasil penelitian berbeda dapat dilihat dalam penelitian Mayangsari (2004) yang justru menemukan bahwa perusahaan yang laporan kuangannya diaudit oleh Kantor Akuntan Publik Big Four tidak memberikan dampak signifikan pada investor untuk dapat memprediksi masa depan yang lebih baik. Ukuran KAP yang besar tidak selalu mencerminkan kualitas audit yang lebih baik karena hasil penelitian menunjukkan variasi keduanya dianggap cukup seragam. Hal ini juga yang mendorong penulis untuk mencoba meneliti dengan salah satu variabel kualitas audit.

\section{Harga Saham}


Saham dalam penelitian ini adalah surat berharga berbentuk sertifikat dan ditransaksikan dalam bursa di dalamnya mencerminkan kepemilikan suatu perusahaan. Dalam penelitian sebelumnya harga saham adalah nilai penyertaan modal pada Perseroan Terbatas yang terdaftar di bursa efek, sudah terjual dan beredar (diperjualbelikan) di bursa (outstanding securities). Harga saham adalah selisih harga perolehan dan harga jual yang diharapkan oleh investor saat melakukan investasi, bisa juga berbentuk dividen. Harga saham yang digunakan dalam penelitian ini adalah harga penutupan (closing price) yang diminta oleh penjual, identifikasi waktunya adalah 3 bulan setelah tutup buku dengan harapan harga saham penutupan tersebut menggambarkan reaksi pasar atas informasi laporan keuangan yang telah diaudit.

Investor lebih tertarik menginvestasikan uangnya dalam saham perusahaan yang harga sahamnya meningkat dari waktu ke waktu dan membagikan dividennya. Harga terbentuk dari kekuatan penawaran dan permintaan pasar, oleh karena itu pada permintaan pasar yang tinggi dan terbatasnya jumlah saham yang diterbitkan akan berakibat pada naiknya harga saham perusahaan.

\section{Pengembangan Hipotesis}

Jennings et al. (2000) dalam penelitiannya memberikan kritikan atas pendekatan amortisasi yang tidak memperlihatkan nilai sesungguhnya dari aktiva, dalam pandangan penelitiannya, reduksi goodwill diasumsikan mengurangi laba dan akan menurunkan nilai saham perusahaan. Dalam hal ini nilai perusahaan akan mempengaruhi perilaku investor dalam melakukan investasi dan tercermin dalam harga saham.

Kajian akan goodwill dalam penelitian akuntansi terus muncul khususnya akan pengakuan nilai goodwill seperti penelitian goodwill pada perusahaan manufaktur untuk melihat nilai perusahaan Chauvin (1994), dan Amir et al. (1993). Dari beberapa penelitian sebelumnya dapat disimpulkan bahwa goodwill berhubungan dengan market to book ratio dan masih memandang goodwill sebagai sebuah aktiva.

Peneliti yang menggunakan pendekatan nilai ekonomis dari goodwill juga menemukan bahwa goodwill memiliki relevansi nilai, seperti penelitian yang dilakukan oleh Senthilnathan (2010) yang menemukan bahwa amortisasi goodwill yang positif menunjukkan hubungan yang positif signifikan dengan pendapatan bulanan. Hal ini menunjukkan kalau investor mungkin mempertimbangkan amortisasi goodwill positif merepresentasikan penciptaan elemen kekayaan di perusahaan.

Nilai buku ekuitas merupakan faktor penentu relevansi nilai harga saham, oleh karena harga saham menentukan nilai (Ohlson, 1995; Indra et al. 2004) perusahaan dan nilai perusahaan tercermin pada nilai kekayaan bersih atau total ekuitas yang dimiliki perusahaan.

Earning per Share (EPS) berpengaruh pada harga saham diungkapkan oleh Setiyanto and Hadi (2013) dengan argumen: dengan semakin tinggi EPS akan mendorong semakin banyak investor yang akan membeli saham, hal ini akan berakibat pada peningkatan harga saham.

Dari penelitian sebelumnya yang melihat kajian antara goodwill dan harga saham maka hipotesis pertama yang dikembangkan adalah:

H1: goodwill, EPS dan Nilai Buku Ekuitas Minus Goodwill berpengaruh pada harga saham (memiliki relevansi nilai).

Goodwill menjadi topik yang paling menarik untuk diteliti karena merupakan bagian aktiva tidak berwujud. Hal ini menyebabkan goodwill banyak ditentukan dengan penilaian subyektif manajemen. Akuntansi goodwill telah lama menjadi masalah teoritis untuk akuntan. Meskipun sebagian besar bisnis memposkan goodwill, akan tetapi akuntan mencatatnya hanya ketika menguntungkan saat mengakuisisi perusahaan lain. Setelah akuisisi, penilaian goodwill memunculkan masalah. Peran auditor tercermin dalam penilaian kembali goodwill dalam proses pemeriksaan untuk menentukan nilai wajar dari aktiva tidak berwujud khususnya goodwill.

Penelitian ini mengembangkan penelitian sebelumnya dengan memasukkan kualitas audit sebagai moderasi yang memperkuat hubungan antara goodwill dan harga saham. Argumentasi yang mendasari adalah pada penetapan nilai goodwill yang sampai saat ini masih menjadi perdebatan oleh karena dalam kenyataan dibeberapa negara sudah menggunakan dasar penilaian nilai wajar. Penilaian goodwill ini membutuhkan justifikasi subyektif dari manajemen dan beberapa standar mengharuskan menggunakan jasa penilai. Peran 
auditor sesuai dengan tujuan audit adalah memastikan perhitungan yang dilakukan benar, logis dan tidak menyalahi standar yang ada karena di dalamnya terdapat kandungan estimasi yang perlu diuji ulang karena dikaitkan dengan risiko salah saji. Oleh karena itu hipotesis kedua yang dikembangkan sebagai berikut:

H2. Kualitas Audit memoderasi pengaruh antara goodwill, EPS dan Nilai Buku Ekuitas Minus Goodwill pada harga saham.

\section{Kerangka Pemikiran}

Kerangka Penelitian dapat dirangkum sebagai berikut:

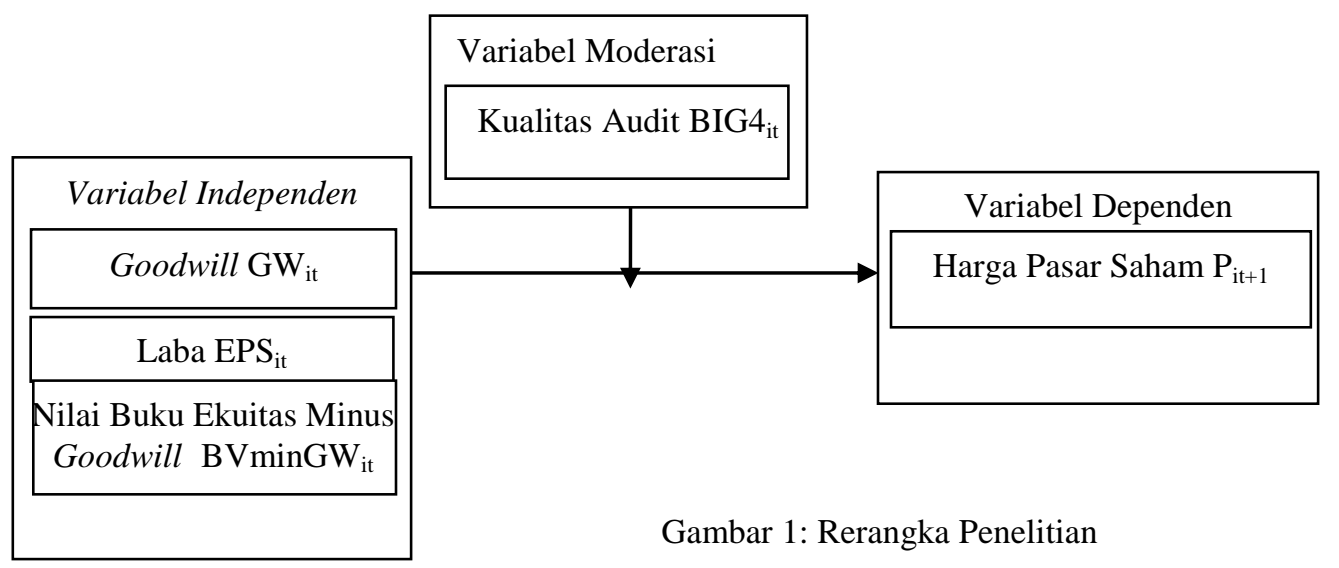

Teknik analisis yang digunakan dalam menguji hipotesis menggunakan model regresi ordinary least square dengan model nilai pasar saham.

\section{METODE PENELITIAN}

Model regresi tersebut dikembangkan dari dari penelitian Ohslon (1995) dan disesuaikan dengan temuan Kanageratnam (2009) yang menyatakan bahwa laba komprehensif lebih kuat berhubungan dengan harga saham dan return dibandingkan dengan Net Income. Dan model yang dikembangkan sebagai berikut:

Model 1: Untuk menguji hubungan antara goodwill, EPS dan Nilai Buku Ekuitas Minus Goodwill dengan Harga Saham

$\mathrm{P}_{\mathrm{it}+1}=\beta_{0}+\beta_{1} \mathrm{GW}_{\mathrm{it}}+\beta_{2} \mathrm{EPS}_{\mathrm{it}}+\beta_{3} \mathrm{BVminGW}_{\mathrm{it}}+\varepsilon_{\mathrm{it}}$

Model 2: Dengan memasukkan variabel kualitas audit dan interaksi kualitas audit yang di proxi kan KAP $B I G 4$ dan Non BIG4

$\mathrm{P}_{\mathrm{it}+1}=\beta_{0}+\beta_{1} \mathrm{BIG}_{\mathrm{it}}+\beta_{1} \mathrm{GW}_{\mathrm{it}}+\beta_{1} \mathrm{GW}^{*} B I G 4_{\mathrm{it}}+\beta_{2} \mathrm{EPS}_{\mathrm{it}}+\beta_{2} \mathrm{EPS}^{*} B I G 4_{\mathrm{it}}+\beta_{3} \mathrm{BVminGW}_{\mathrm{it}}+\beta_{3}$

$\mathrm{BvminGW}^{*} B I G 4_{\mathrm{it}}+\varepsilon_{\mathrm{it}}$

Keterangan:

Variabel

$\mathrm{P}_{\mathrm{t}-1}$

BVminGW $_{\text {it }}$ Nilai Book Value Ekuitas setelah dikurangi jumlah goodwill per lembar dari perusahaan $_{\text {i }}$ per tahun $_{\mathrm{t}}$

EPS $_{\text {it }} \quad$ Laba Per lembar saham bersih per tahun perusahaan ${ }_{i}$ di akhir tahun ${ }_{t}$

$\mathrm{GW}_{\text {it }} \quad$ Goodwill, per lembar saham di perusahaan i pada akhir tahun ${ }_{\mathrm{t}}$

$B I G 4_{\text {it }} \quad$ Audit Quality yang didefinisikan KAP yang masuk BIG4

\section{Operasionalisasi Variabel}

Variabel Kontrol : 


\section{Book Value Minus goodwill (BVminGWit):}

Kajian akan goodwill dalam penelitian akuntansi terus muncul khususnya akan pengakuan nilai goodwill seperti penelitian Chauvin (1994), pada penelitian Chauvin goodwill digunakan untuk melihat nilai perusahaan dan mengkaitkan amortisasi goodwill dengan nilai perusahaan yang berdampak pada harga saham dalam penelitian. Dalam penelitian Amir (1993) yang menguji relevansi nilai dan ekuitas pemegang saham, menemukan bahwa goodwill berhubungan dengan market to book ratio dan goodwill dipandang sebagai aset.

\section{Laba Per Lembar Saham (EPSit):}

Laba komprehensif dalam penelitian digunakan Earning Per Share oleh karena dalam penelitian terakhir Kanageratnam (2009) disarankan untuk menggunakan laba komprehensif dibandingkan menggunakan Net Income. Net Income dianggap lebih relevan menggambarkan prediksi aliran kas dimasa mendatang. Dalam penelitian ini peneliti menggunakan nilai jadi Earning per Share yang tersedia di basis data Laporan Laba Rugi perusahaan.

\section{Variabel Independen : Goodwill (GWit ):}

Menurut PSAK 22 goodwill dihitung penurunan nilainya setiap tahun dan dicatat sebesar harga perolehannya dikurangi dengan akumulasi kerugian penurunan nilai, hal tersebut biasanya terjadi dalam proses penggabungan perusahaan. Dalam penelitian ini goodwill diperoleh dari nilai goodwill akhir tahun dibagi dengan jumlah saham beredar.

\section{Variabel Dependen : Harga Saham (Pt-1 ):}

Harga pasar dalam penelitian ini dihitung dengan melihat harga saham pada penutupan tanggal 31 Maret tahun berikutnya dibagi jumlah lembar saham, penetapan tiga bulan setelah laporan keuangan dipublikasi dipilih dengan harapan pada tanggal tersebut semua perusahaan telah mempublikasikan laporan tahunan yang sudah di audit, dan diharapkan dampak relevansi informasi yang dipublikasi sudah terlihat.

\section{Variabel Moderasi : Kualitas Audit (Audit Quality -BIG4it):}

Kualitas audit dalam penelitian ini menggunakan variabel dummy dengan proxi ukuran kantor akuntan publik yang tercermin dalam dua kategori bila termasuk Kantor Akuntan Publik BIG4 akan diberi skor 1 dan bila tidak termasuk Kantor Akuntan Publik BIG4 akan diberi skor 0.

\section{Data dan Sample}

Penelitian ini menggunakan purposive sampling, purposive sampling adalah sampel yang diambil memiliki maksud, tujuan tertentu dan kriteria tertentu. Populasi data yang digunakan diambil dari perusahaan non keuangan yang terdaftar di Bursa Efek Indonesia pada tahun 2014 - 2017 empat periode akuntansi tersebut dimaksudkan untuk memperoleh gambaran yang lebih luas dan memenuhi kecukupan data untuk di proses.

Sampel dipilih memenuhi kriteria tertentu yaitu 1) perusahaan yang sudah terdaftar di Bursa Efek sejak tahun 2014,2 ) perusahaan yang terdaftar di BEI yang bukan keuangan selama periode 2014-2017, 3) perusahaan yang melaporkan goodwill, 4) perusahaan yang memiliki data lengkap untuk keperluan variabel diluar goodwill selama periode 2014-2017, 5) periode akuntansi yang dipakai yang berakhir tanggal 31 Desember, 6) nilai buku ekuitas perusahaan tidak negatif selama periode 2014-2017. Pemilihan sektor non keuangan bertujuan untuk menghindari adanya industrial effect oleh karena industri keuangan memiliki karakteristik yang sangat berbeda.

\section{Metode Pengumpulan Data}

Sumber data penelitian ini adalah data sekunder yang diperoleh basis data Eikon dan juga dilakukan juga pencocokan data laporan tahunan yang diperoleh dari web Bursa Efek Indonesia (www.idx.co.id) dan Pusat Data Ekonomi dan Bisnis FEUI (PDBE UI). Data yang diambil lewat basis data Thomson Reuters Eikon adalah nilai buku ekuitas, jumlah saham beredar, goodwill laba per lembar saham pada tanggal 31 Desember 
tahun $\mathrm{t}$, data harga saham per lembar tanggal 1 april tahun $\mathrm{t}+1$ dan Code Auditor yang mencerminkan nama auditor tiap perusahaan.

\section{HASIL DAN PEMBAHASAN}

\section{Hasil Analisis}

Sampel dalam penelitian ini menggunakan purposive judment sampling dengan melihat populasi seluruh perusahaan non-keuangan yang terdaftar di Bursa Efek Indonesia sejak tahun 2014 sampai dengan tahun 2017. Total perusahaan non keuangan yang terdaftar di BEI sebanyak 458 perusahaan. Dengan berdasarkan kriteria yang telah ditetapkan maka diperoleh total sampel sebanyak 71 perusahaan.

Analisis Deskriptif

Tabel 1: Statistik Deskriptive

\begin{tabular}{|l|c|r|r|r|r|r|}
\hline \multicolumn{1}{|c|}{ Variabel } & n & \multicolumn{1}{c|}{ Minimum } & \multicolumn{1}{c|}{ Maksimum } & \multicolumn{1}{c|}{ Rata-Rata } & \multicolumn{1}{c|}{ Median } & \multicolumn{1}{c|}{ Std. Deviasi } \\
\hline $\mathrm{P}_{\mathrm{t}-1}$ & 71 & 52 & $54.500,00$ & $2.192,567$ & 671,00 & $5.045,658$ \\
\hline $\mathrm{BVminGW}_{\text {it }}$ & 71 & 7,45 & $27.435,90$ & 953,644 & $10.143,78$ & $2.343,643$ \\
\hline $\mathrm{EPS}_{\text {it }}$ & 71 & $.-192,67$ & $6.204,34$ & 182,450 & $1.002,00$ & 582,532 \\
\hline $\mathrm{GW}_{\text {it }}$ & 71 & 0 & $7.289,33$ & 117,768 & 4.230 & 751,967 \\
\hline BIG4 $_{\text {it }}$ & 71 & 0 & 1 & 0,4 & 0,5 & 0,1 \\
\hline
\end{tabular}

Sumber : Keluaran software Stata yang telah diolah

Variabel harga saham (Pt-1) memiliki nilai minimum Rp52 per lebar dan maksimum Rp54.500,00 dengan rata-rata harga saham sebesar Rp2.192,5677. Menunjukkan sekitar 68\% perusahaan berada pada rentang kapitalisasi ekuitas $(2.192,567 \pm 5.045,658)$. Rata-rata nilai BvminGW sebesar Rp953,644 per lembar saham dengan standar deviasi 2.343,643. Hal tersebut memperlihatkan variabel BvminGWmemiliki sebaran data yang luas dibandingkan variabel EPS dan Goodwill. Standar deviasi BvminGW empat kali lebih besar dibandingkan standar deviasi rata-rata EPS.

Pada variabel EPS nilai minimum Rp.-192,67 per lembar saham dan nilai maksimum Rp6.204,34 per lembar saham. Angka minimum EPS negatif menunjukkan terdapat perusahaan mengalami kerugian, EPS dengan rata-rata sebesar Rp182,450 dan standar deviasi 582,532 bermakna sebaran data dominan di perusahaan dengan EPS relatif kecil. Untuk variabel goodwill (GW) rata-rata sebesar Rp117,768 per lembar saham dengan standar deviasi 751,967. Data tersebut dapat bermakna bahwa banyak perusahaan memiliki nilai goodwill relatif kecil. Nilai goodwill minimum tercatat sebesar Rp.0 per lembar saham dan nilai maksimumnya Rp7.289,33 per lembar di periode tertentu.

\section{Penentuan Model Panel}

Pada model panel dilakukan pengujian statistik untuk melihat apakah model yang digunakan menggunakan Fixed Effect (FE), Random Effect (RE) atau Pooled Least Square (PLS). Hasil analisis statistik Uji Chow, uji LM dan Uji Hausman memperlihatkan p-value $<0,05$, sehingga dapat disimpulkan model panel lebih sesuai bila diuji dengan pendekatan FE.

\section{Pengujian asumsi BLUE}

Uji asumsi BLUE memperlihatkan nilai VIF pada variabel EPS sebesar 11,45, BvminGW sebesar 6,15 dan GW sebesar 6,62 hal ini memperlihatkan terdapat masalah multikolinieritas. Sedangkan nilai $C h i^{2}(52)$ sebesar 23e+23 dan Prob >chi ${ }^{2}$ sebesar 0,0000, hal ini mengindikasikan Terdapat masalah heterokedasitas. Untuk multikolinieritas terjadi karena kurangnya data dalam penelitian, dengan asumsi model yang digunakan sudah teruji yaitu model Ohslon (1995) perlakuan multikolinieritas diabaikan. Masalah heterokedasitas dengan menguji model menggunakan Generalized Least Square (GLS).

\section{Pengujian Model 1: Relevansi Nilai Goodwill}

Pengujian dilakukan dengan software STATA dan model diregresikan dengan metode Generalized Least Square (GLS). Hasil pengujian di rangkum dalam tabel 2: 
Tabel 2: Hasil Regresi Hipotesis 1

\section{Model Hipotesis 1}

$\mathbf{P}_{\mathrm{it}+1}=\beta_{0}+\beta_{1} \mathbf{G W}_{\mathrm{it}}+\beta_{2} \mathbf{E P S}_{\mathrm{it}}+\beta_{3}$ BVminGW $_{\mathrm{it}}+\varepsilon_{\mathrm{it}}$

H1: goodwill, EPS dan Nilai Buku Ekuitas Minus Goodwill berpengaruh pada harga saham perusahaan (memiliki relevansi nilai)

\begin{tabular}{|c|c|c|c|}
\hline Variabel & Coefficient $^{b}$ & $Z-S t a t^{b}$ & Prob $>I z I^{b}$ \\
\hline BVminGW & 0,0987 & 1,32 & $0,086^{*}$ \\
\hline EPS & 3,2909 & 4,50 & $0,000 * * *$ \\
\hline GW & $-8,2081$ & $-3,65$ & $0,000^{* * *}$ \\
\hline $\mathbf{R}-$ Squared & 0,0796 & No. Observ. & 71 \\
\hline F - Stat $^{b}$ & 5,01 & Wald chi - squ & 4790,12 \\
\hline Prob (F-Stat) & $0,0022 * * *$ & Prob $\left(\mathrm{chi}^{2}\right)$ & $0,0000 * * *$ \\
\hline
\end{tabular}

$\mathbf{P}=$ harga penutupan pasar saham tiga bulan setelah tanggal 31 Desember; BVminGW=Nilai buku ekuitas dikurangi nilai goodwill; EPS=laba per lembar saham; GW= nilai goodwill tercata di laporan keuangan perusahaan; ***signifikan pada $\alpha 1 \%$; ** signifikan pada $\alpha 5 \%$; signifikan pada $\alpha 10 \%$

${ }^{a}$ diuji pada model regresi LSDV untuk model FE (perintah STATA: xtreg depvar indepvar, fe); $\quad{ }^{b}$ diuji pada model regresi LSDV yang dimodifikasi dengan model GLS untuk model FE (perintah STATA: xi;xtgls depvar indepvar i. individu)

Sumber: Ouput software statistik Stata yang telah diolah

Signifikan model pertama untuk hipotesis 1 memperlihatkan F-stat sebesar 0,0022 dengan nilai alpha lebih kecil 1\%, dapat disimpulkan bahwa variabel EPS, GW dan BminGW secara bersama-sama memprediksi nilai variabel harga saham P. Nilai R-Square 0,0796 atau bermakna variasi variabel dependen dijelaskan oleh variasi variabel independen sebesar 7,96\%, sisanya 92,04 dijelaskan oleh faktor-faktor lain diluar penelitian.

Koefisien variabel BVminGW sebesar positif 0,0987 dan p-value sebesar 0,086 lebih kecil dari $\alpha 10 \%$ mengindikasikan nilai buku ekuitas dikurangi goodwill signifikan dan mempengaruhi nilai pasar saham perusahaan. Koefisien variabel EPS sebesar positif 3,2909 dan p-value sebesar 0,000 lebih kecil dari $\alpha 1 \%$ mengindikasikan nilai laba per lembar saham berpengaruh signifikan pada nilai pasar saham perusahaan. Koefisien variabel GW sebesar -8,2081 dan p-value sebesar 0,000 lebih kecil dari $\alpha 1 \%$ mengindikasikan nilai goodwill berpengaruh signifikan negatif pada nilai pasar saham perusahaan

Hasil ini konsisten dengan hipotesis satu yang menyatakan bahwa goodwill berpengaruh pada harga saham (memiliki nilai relevansi).

\section{Pengujian Model 2: Relevansi Nilai goodwill dengan moderasi kualitas audit}

Pengujian model ke dua dilakukan dengan software STATA dan model diregresikan dengan metode Least Square Dummy Variable (LSDV).

Tabel 3: Hasil Regresi Hipotesis 2

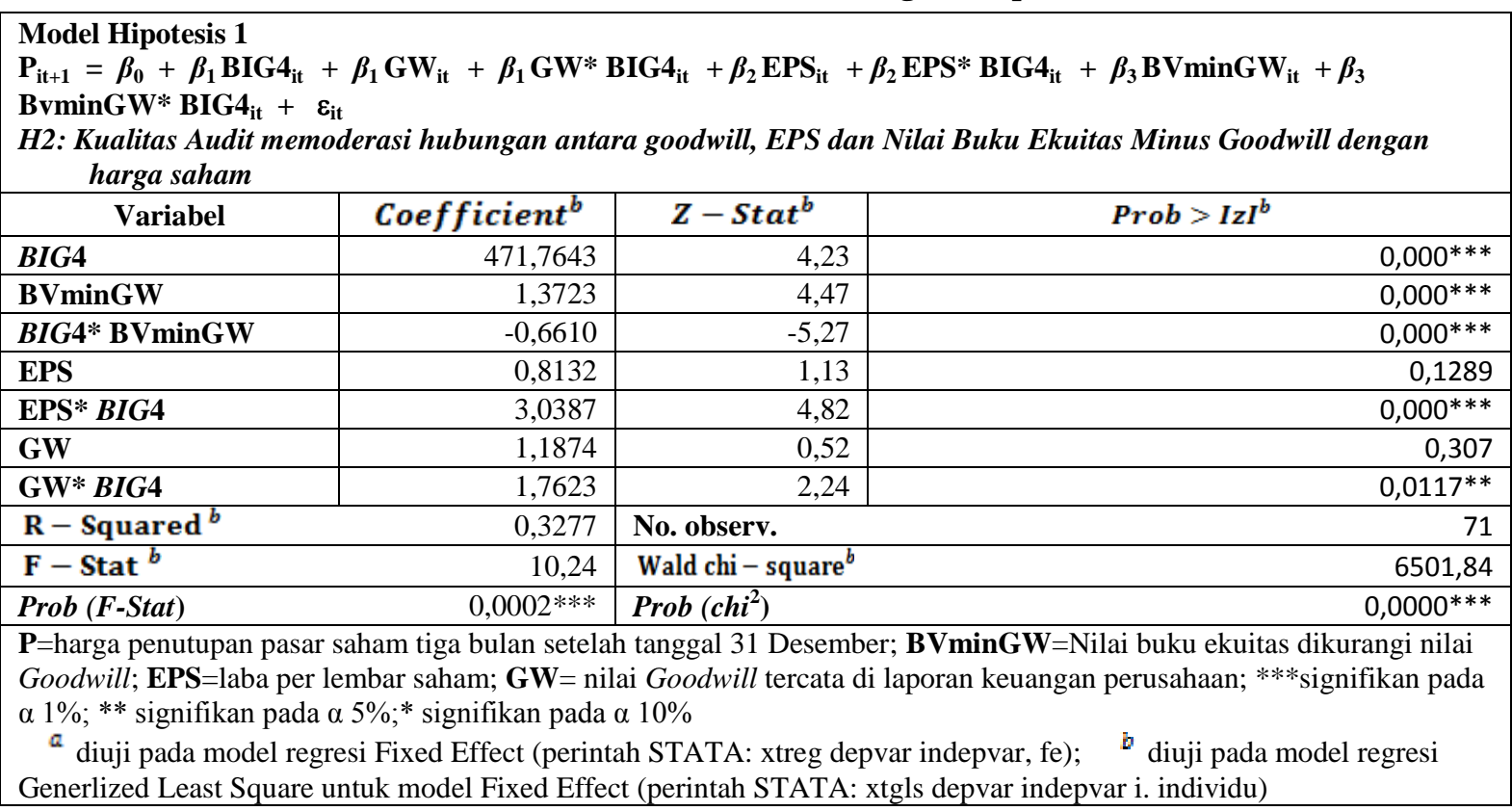

Sumber: Ouput software statistik Stata yang telah diolah 
Signifikan model pertama untuk hipotesis 1 memperlihatkan $F$-stat sebesar 0,0002 dengan nilai alpha lebih kecil 1\%, dapat disimpulkan bahwa variabel EPS, GW dan BminGW secara bersama-sama memprediksi nilai variabel harga saham P. Nilai $R$-Square 0,3277 atau bermakna variasi variabel dependen dijelaskan oleh variasi variabel independen sebesar 3,27\%, sisanya 96,73 dijelaskan oleh faktor-faktor lain diluar penelitian.

Koefisien variabel BVminGW dengan interaksi kualitas audit memiliki p-value sebesar 0,000 lebih kecil dari $\alpha 1 \%$ dan bernilai negatif sementara di model pertama sebelum ada interaksi mengindikasikan nilai buku ekuitas positif. Dapat dikatakan relevansi nilai BVminGW menurun setelah ada interaksi kualitas audit (BIG4). Variabel EPS*BIG4 memiliki koefisien positif dan $p$-value sebesar 0,000 lebih kecil dari $\alpha 1 \%$ mengindikasikan relevansi nilai laba per lembar saham dalam mempengaruhi nilai pasar saham perusahaan. Signifikan variabel GW dengan p-value sebesar 0,307 tidak signifikan sementara setelah ada interaksi dengan kualitas audit (BIG4) menjadi signifikan dengan nilai $p$-value 0,0117 mengindikasikan kualitas audit meningkatkan relevansi nilai dari goodwill.

Hasil ini konsisten dengan hipotesis kedua yang menyatakan bahwa kualitas audit memoderasi berpengaruh goodwill pada harga saham (memiliki nilai relevansi).

\section{KESIMPULAN DAN SARAN}

Penelitian ini bertujuan menguji relevansi nilai informasi goodwill dan melihat dampak variabel moderasi kualitas audit pada relevansi nilai goodwill. Dengan sampel sebesar 71 perusahaan non keuangan dapat disimpulkan:

1.Sesuai hipotesis pertama yang memprediksi pengaruh goodwill pada harga saham (memiliki relevansi nilai), hasil penelitian menunjukkan goodwill berhubungan negatif signifikan terhadap harga saham. Investor dan analisis informasi menggunakan nilai goodwill untuk mengevaluasi nilai perusahaan hasil ini konsisten dengan penelitian Oliveira et al. (2010). Sedangkan Nilai Buku minus Goodwill dan EPS berpengaruh positif pada harga saham.

2.Sesuai hipotesis kedua yang menyatakan Kualitas Audit memoderasi pengaruh antara goodwill pada harga saham. Hasil penelitian menunjukkan bahwa kualitas audit memang meningkatkan relevansi nilai goodwill. Peningkatan ini membuat peran auditor dalam melakukan penilaian ulang atas nilai goodwill yang akurat menjadi penting. Begitu juga pada pengaruh moderasi kualitas audit pada hubungan EPS dan harga saham diperoleh hasil yang sama.

\section{Keterbatasan dan Saran Penelitian Selanjutnya:}

Beberapa kendala yang dapat menjadi keterbatasan penelitian ini adalah randahnya jumlah sampel perusahaan yang ada dalam penelitian ini oleh karena sedikitnya informasi goodwill yang tersedia. Peneliti selanjutnya dapat menggunakan informasi tambahan agar data goodwill lebih akurat atau menambahkan jumlah sampel dengan memperluas cakupan penelitian. Peneliti selanjutnya juga dapat mengganti proksi kualitas audit selain ukuran KAP misalkan dengan audit tenure.

\section{REFERENSI}

Amir, E. M., Harris, T. S., \& Venuti, E. K. (1993). A Comparison of the Value Relevance of U.S. versus Non-U.S. GAAP Accounting Measures Using Form 20-F Reconciliations. Journal of Accounting Research, 31 (Supplement), 230-264.

Barth, M. E., Beaver, W. H., \& Landsman, W. R. (2001). The Relevance of the Value Relevance Literature for Financial Accounting Standard Setting: Another View. Journal of Accounting and Economics, 31, 77-104.

Barth, M. E., Beaver, W. H., \& Wolfson, M. (1990). Components of Earnings and The Structure of Bank Share Prices. Financial Analyst Journal, 53-60.

Bloom, M. (2009). Accounting for Goodwill. Abacus-A Journal of Accounting, 45 No.3, 379-389.

Camara, N. D. (2007). Accounting and Valuation of Intangible Assets. Henley Manager Update, 18 No. 4 , 11-18. 
Chauvin, K.W., Hirschey, M. (1994). Goodwill, Profitability, and Market Value of the Firm. Journal of Accounting and Public Policy, 13 (2), 159-180.

DeAngelo, L. E. (1981). Auditor Size dan Audit Quality. Journal of Accounting and Economics, 3, 183-199.

Francis, J. R. (2011). A Framework for Understanding and Researching Audit Quality. Auditing. A Journal of Practise \& Theory, 30 No.2.

Hidayat, T. (2012). Pengaruh ukuran KAP dan Auditor Tenure terhadap Value Relevance dari nilai wajar. Jurnal Akuntansi dan Keuangan Indonesia, 9 No.2.

Ikatan Akuntan Indonesia. (2010). Standar Akuntansi Keuangan. Jakarta: Salemba Empat.

Indra, Syam, \& Fazli (2004). "Hubungan Laba Akuntansi, Nilai Buku, Dan Total Arus Kas Dengan Market Value : Studi Akuntansi Relevansi Nilai”. Simposium Nasional Akuntansi VII, Denpasar Bali, 2-3 Desember 2004, 931 - 944

Jennings, R., Robinson, J., Thompson, R \& Duvall, L. (2000). The Relation Between Accounting Goodwill Numbers and Equity Values. Journal of Business Finance \& Accounting, 23, 513-534.

Johnson, J., \& Tearney, M. (1992). Goodwill: an Eternal Controversy, The CPA Journal, 63 No.4, 58-69.

Kanagaretnam, K., Mathieu, R., \& Shehata, M., (2009). Usefulness of Comprehensive Income Reporting in Canada. Journal of Accounting and Public Policy, 28(4), 349-365.

Lako, A. (2006). Relevansi Nilai Informasi Laporan Keuangan untuk Pasar Saham: Pengujian Berbasis Teori Valuasi dan Pasar Efisien. Disertasi Universitas Gadjah Mada.

Lee, B. B., Cox, S., \& Roden, D. (2007). Have The Big Accounting Firms Lost Their Audit Quality Advantage? Evidence From The Returns-Earnings Relation. Journal of Forensic Accounting, VIII, 271-286.

Lo, K., \& Lys, T. (2000). The Ohlson Model: Contribution to Valuation Theory, Limitation, and Empirical Application. Journal of Accounting, Auditing \& Finance, 15, 337-367.

Maines, L. A., \& Wahlen, J. M. (2006). The Nature of Accounting Information Reliability: Inferences From Archiveland Experimental Research. Accounting Horizons, 20(4), 399-425.

Mayangsari, S., \& Wilopo (2002). Konservatisme Akuntansi, Value Relevance dan Discretionary Accruals: Implikasi Empiris Model Feltham-Ohlson (1996). Jurnal Riset Akuntansi Indonesia, 5 No.3, 291-310.

Mayangsari, S. (2004). Bukti Empiris Pengaruh Spesialisasi Industri Auditor terhadap Earnings Response Coefficient. Jurnal Riset Akuntansi Indonesia, 7 No.2.

Ohslon, J. (1995). Earning, Book Values, and Dividends in Security Valuation. Contemporary Accounting Research, 11 (2), 661-688.

Oliveira, L. Rodrigues, Lucia, L., \& Russel C. (2010). Intangible Assets and Value Relevance: Evidence from The Portuguess Stock Exchange. The British Accounting Review.

Ramanna, K., \& Watts, R. L. (2009). Evidance from Goodwill on the Effect's of Using Unverifiable Estimates in Financial Reporting. Working paper Harvard Business School.

Richardson, V. J., \& Hirschey, M. (2002). Information Content of Accounting Goodwill Numbers. Journal of Accounting and Public Policy, 21, 173-191.

Senthilnathan S., (2010). Testing the Relevance of Goodwill Amortisation within the Ohlson (1995). Value Relevance Model Using Share Returns. SSRN working paper.

Setiyanto, A. I. \& Hadi, A. (2013). Analisis Pengaruh Fundamental Terhadap Harga Saham Studi pada Perusahaan Sektor Properti di Asia Tenggara Tahun 2008-2012. Jurnal Manajemen dan Bisnis.

Suwardi, E. (2005). Value Relevance of Accounting Numbers: Evidence from the Jakarta Stock Exchange (JSX). Jurnal Akuntansi dan Auditing Indonesia, 9 No.1, 23-29. 